\title{
Research on Influence of Some Post-harvest Change of Peach Genotypes
}

\author{
Carmen BEINŞAN ${ }^{1 *}$, Radu SUMALAN ${ }^{1}$, Sorin VÂTCĂ ${ }^{2}$ \\ ${ }^{1}$ Faculty of Horticulture and Forestry, Banat University of Agricultural Sciences and Veterinary \\ Medicine Timisoara \\ Calea Aradului, 119, 300645, Timisoara, Romania \\ ${ }^{2}$ Faculty of Agriculture, University of Agricultural Sciences and Veterinary Medicine Cluj - Napoca \\ Calea Mănăștur 3-5, 400372, Cluj-Napoca , Romania \\ *Corresponding author: hortic2002@yahoo.com \\ Bulletin USAMV series Agriculture 72(2)/2015 \\ Print ISSN 1843-5246; Electronic ISSN 1843-5386 \\ DOI 10.15835/buasvmcn-agr: 11722
}

\begin{abstract}
In this experiment we studied the influence of storage conditions on some quality indices of two peach varieties present on the market in western part of Romania.

The biological material was represented by two varieties of peach, fruit which is sold on market in western Romania, having the following origin Turcia and Chile. During the experiment the following parameters were studied: fruit's dimensions (diameter, fruit length, circumference, weight, and fruit color), flesh firmness, acidity vegetable juice, soluble carbohydrate content and dry matter. To determine fruit firmness we used a digital penetrometer. The percentage of dry fruit pulp was determined using Kern thermobalance. Storage conditions were: temperature $4{ }^{\circ} \mathrm{C}$, for 5 and 10 days.

After 10 days of storage, due to post-maturation processes, especially respiration (degradation of the organic substrate) there was a reduction of the circumference, the diameter of the fruits and their color as changed. As regarding the biochemical characteristics, after 5 days of conservation can be seen a reduction in fruit firmness, however there is an increase of soluble carbohydrate content, while vegetable juice acidity and dry matter percentage recorded no significant changes. In case of biochemical parameters after 10 days of conservation there is a continuous trend to increase the soluble carbohydrate content due to conversion of starch into glucose after enzymatic hydrolysis processes and also there is a sharp decrease in fruit firmness, but also a slight decrease of the juice acidity from the pulp of the fruit.
\end{abstract}

Keywords: dry matter, firmness, post-harvest, Prunus persica.

\section{INTRODUCTION}

Fruit maturation represent the vegetative phase from the beginning of fruit ripening and continuing with maximum accumulation of organoleptic qualities, in other words, the achievement of consumption maturity (Blankenship, 2003). In all this time, in fruits occur a lot of physiological and biochemical processes from which result modifications of color, consistency, juicy and taste of fruits. Fresh fruits and vegetables are highly perishable commodities that can easily spoil or deteriorate during produce handling along the supply chain from the producer to the final retailer.

All fruits and vegetables are living parts of plants containing 65 to 95 per cent water. They continue their life metabolisms after harvest and thus change their characteristics depending on product handling, storage and treatment, all of witch have a decisive impact on the life of the product.

Postharvest factors can be optimized in such a way that even when certain preharvest factors are suboptimal, browning incidence can be prevented 
to a large degree. Postharvest factors that influence the development of browning disorders are the picking date, the duration of the cooling period, the $\mathrm{CO}_{2}$ and $\mathrm{O}_{2}$ partial pressure, the storage temperature and storage duration (Blanpied, 1975; Lammertyn et al., 2003).

Apples, peaches and pears have a wide range between climatic minimum and maximum level, in conclusion best possibilities of storage and transportation. The maximum storage duration will depend on: variety of fruit, how ripe the fruit at harvest - that are less ripe fruit will keep longer and in better conditions than soft fruit, as fruit is cooled quickly and efficiently (Franck et al., 2007).

\section{MATERIALS AND METHODS}

The biological material was represented by two varieties of peach, fruit which is sold on market in western Romania, having the following origin Turcia and Chile. During the experiment the following parameters were studied: fruit's

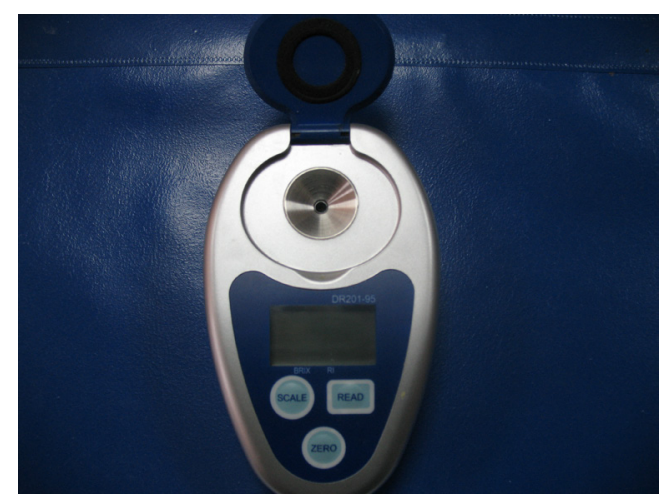

Fig. 1 Digital refractometer -original

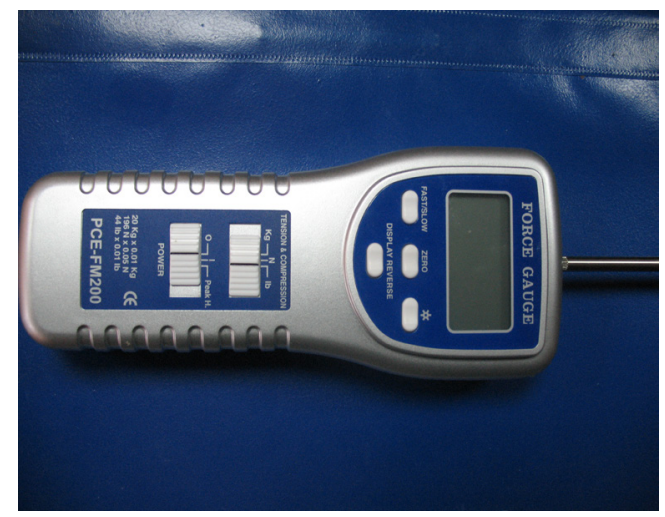

Fig. 3 Penetrometer - original dimensions (diameter, fruit length, circumference, weight and fruit color), flesh firmness, acidity vegetable juice $(\mathrm{pH})$, soluble carbohydrate content and dry matter. Biometric characteristics (diameter, length, circumference of fruit) were determined using digital caliper.

Firmness is the best indicator of the maturity of stone fruit. With the maturation of the fruit, the pulp becomes softer. To determine fruit firmness we used a digital penetrometer, removing the two small disks of peeled fruit in the middle of the dry flower stems and opposite sides of the peach. For determination of the $\mathrm{pH}$, the fruits were scraped off, after which $30 \mathrm{ml}$ were squeezed juice from the pulp, which is then introduced into the $\mathrm{pH}$-meter. When parameters have been made to stabilize readings.

Soluble carbohydrate content was achieved with digital refractometer, Brix degrees was equated to the percentage depending on the temperature determination.

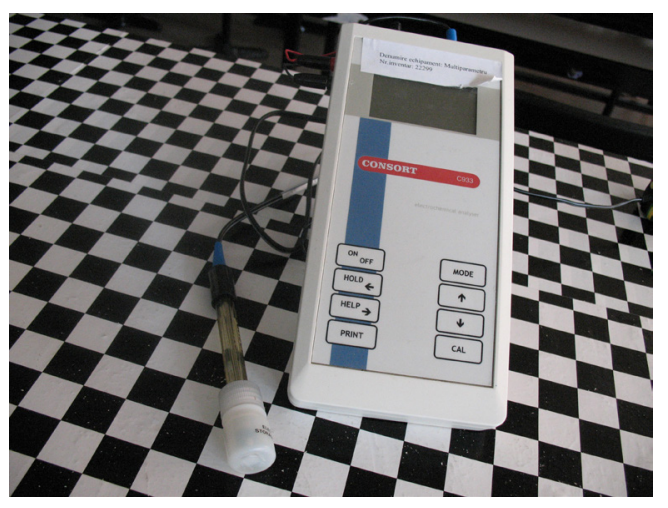

Fig. 2 Multiparameter -original

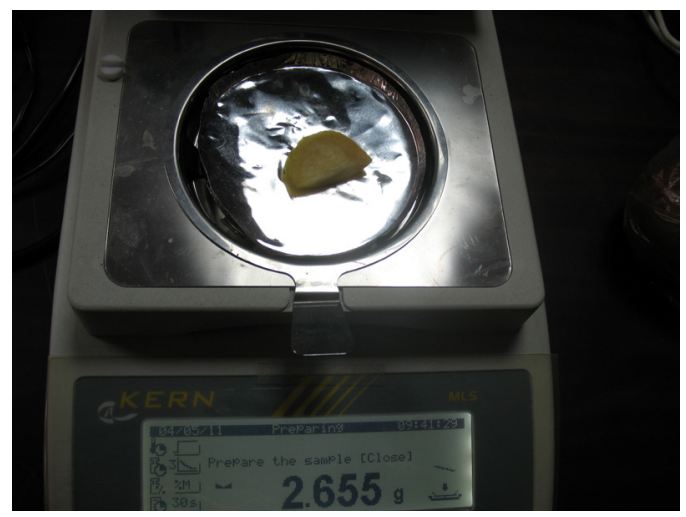

Fig. 4 Kern thermobalance- original 
The percentage of dry fruit pulp was determined using Kern thermobalance. Storage conditions were: temperature $4{ }^{\circ} \mathrm{C}$, for 5 and 10 days.

\section{RESULTS AND DISCUSSION}

Ripening phase of fruit at harvest moment greatly affects the quality of peaches and nectarines on their circuit through the post-harvest operations and commercialization. Ensuring that the fruits are harvested at optimum maturity stage will offer the best potential for maximum possible storage term and will maximize the opportunity to get high quality fruit for storage.

As regards peaches and nectarines, the main physiological change indicating the level of maturity of the fruit is internal production of phyto-hormone ethylene $\left(\mathrm{C}_{2} \mathrm{H}_{4}\right)$ - a naturally occurring hormone that causes a cascade of biochemical reactions involved in ripening. The ethylene produced at the time of of the fruit ripening causes ripening of the fruit, that makes it softer, produce volatile compounds (aroma and flavor), converts starch into glucose, develops skin color and decompose green chlorophyll. Such fruits such as peaches and nectarines, that produce the ethylene in ripening process is called climacteric fruit (Tonutti et al., 1996).
After analyzing the main biometric parameters it was found that after keeping for 5 days at $4^{\circ} \mathrm{C}$ there were no obvious modifications, also fruit color remained unchanged (Tab. 1, Tab. 2).

After 10 days of storage, due to post-maturation processes, especially respiration (degradation of the organic substrate) there was a reduction of the circumference, the diameter of the fruits and their color as changed (Tab. 3, Tab. 4). Peaches, like many other climateric fruits, ripening accelerates after harvesting, in comparison with the fruits remaining on the trees (Abeles et al., 1992; Budde et al., 2000).

The greatest weight and diameter variety belongs to Turkey with an average weight of $181.73 \mathrm{~g}$ and $6.81 \mathrm{~cm}$ after 10 days of storage (Tab. 4).

In the case of physical parameters both types of peaches studied registered values that are significantly close due to their classification in the same class quality, A. (Tab. 5).

Fruit maturation involves a series of biochemical reactions and structural changes which have the fruits acceptable for consumption. In climacteric fruit, such changes are in accordance with the control of ethylene, a plant hormone (Pech et al., 1994). The sharp rise in ethylene synthesis occurs in the opening of the beginning of

Tab. 1. The main biometric characteristics of fruits - Peaches from Chile ( 5 days of storage)

\begin{tabular}{cccccc}
\hline $\begin{array}{c}\text { Number of } \\
\text { days }\end{array}$ & $\begin{array}{c}\text { Diameter } \\
(\mathrm{cm})\end{array}$ & $\begin{array}{c}\text { Circumference } \\
(\mathrm{cm})\end{array}$ & Length $(\mathrm{cm})$ & Weight $(\mathrm{g})$ & Fruit color \\
\hline 1 & $6.83 \pm 0.04$ & $22.63 \pm 0.07$ & $6.56 \pm 0.68$ & $182.03 \pm 1.02$ & yellowish red \\
\hline 2 & $6.82 \pm 0.06$ & $22.63 \pm 0.34$ & $6.56 \pm 0.34$ & $182.03 \pm 0.97$ & yellowish red \\
\hline 3 & $6.82 \pm 0.15$ & $22.63 \pm 0.02$ & $6.56 \pm 0.41$ & $182.03 \pm 1.24$ & yellowish red \\
\hline 4 & $6.82 \pm 0.21$ & $22.62 \pm 0.35$ & $6.55 \pm 0.03$ & $182.01 \pm 1.15$ & yellowish red \\
\hline 5 & $6.81 \pm 0.09$ & $22.62 \pm 0.87$ & $6.55 \pm 0.07$ & $182.01 \pm 0.78$ & yellowish red \\
\hline
\end{tabular}

Tab. 2. The main biometric characteristics of fruits - Peaches from Turcia (5 days of storage)

\begin{tabular}{cccccc}
\hline $\begin{array}{c}\text { Number of } \\
\text { days }\end{array}$ & $\begin{array}{c}\text { Diameter } \\
(\mathrm{cm})\end{array}$ & $\begin{array}{c}\text { Circumference } \\
(\mathrm{cm})\end{array}$ & Length $(\mathrm{cm})$ & Weight $(\mathrm{g})$ & Fruit color \\
\hline 1 & $6.94 \pm 0.20$ & $22.66 \pm 0.61$ & $6.51 \pm 0.09$ & $182.13 \pm 1.14$ & yellowish red \\
\hline 2 & $6.91 \pm 0.46$ & $22.66 \pm 0.25$ & $6.52 \pm 0.06$ & $182.13 \pm 1.34$ & yellowish red \\
\hline 3 & $6.89 \pm 0.68$ & $22.65 \pm 0.88$ & $6.54 \pm 0.14$ & $182.10 \pm 1.79$ & yellowish red \\
\hline 4 & $6.87 \pm 0.04$ & $22.65 \pm 0.22$ & $6.55 \pm 0.50$ & $182.10 \pm 1.25$ & yellowish red \\
\hline 5 & $6.86 \pm 0.02$ & $22.64 \pm 0.16$ & $6.53 \pm 0.06$ & $182.08 \pm 1.08$ & yellowish red \\
\hline
\end{tabular}


the climateric phase which is the key phenomenon in initiating changes in color, flavor and texture (Tonutti et al., 1991; Pech et al., 1994). In the results obtained by Aly et al., (1981) was presented a simultaneous development between ethylene biosynthesis and fruit firmness for peaches and nectarines. This study was conducted to better understand the evolution of ethylene in terms of color, softening and firmness for peaches.

Regarding acidity, the values obtained from the pulp of the fruit, stored at $4{ }^{\circ} \mathrm{C}$, were different

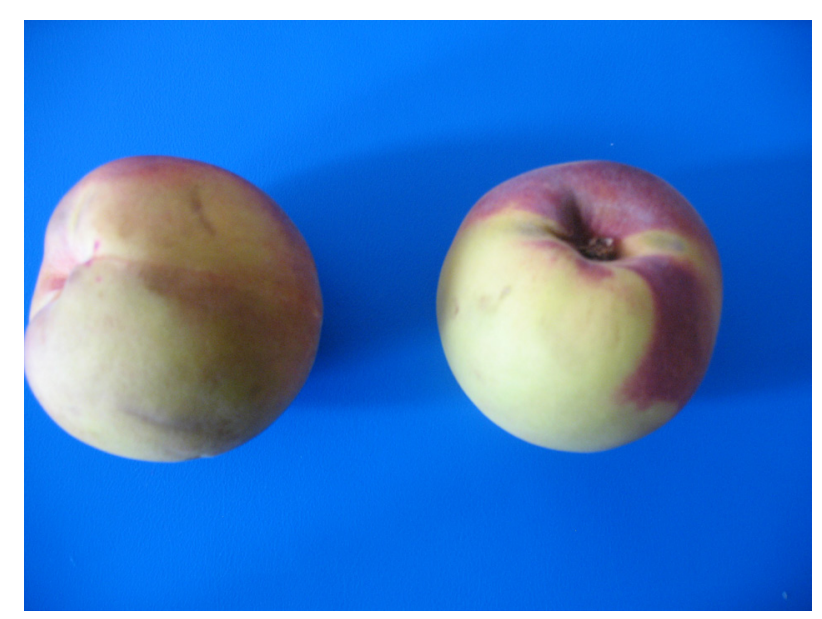

Fig. 5 The two peach genotypes studied in the two genotypes. During the storage has seen a trend of decreasing acidity, the highest value being recorded at the Chile, both after 5 and 10 days (5.76 after 10 days of storage - Fig. 1).

In terms of total soluble carbohydrate content, at the start of the experiment with Turkey fruits had a good percentage of glucose content (10.06\%), while Chile exhibits a low total sugar content $(9.00 \%)$. Following conservation all sorts have recording significant increases of soluble carbohydrate content, the highest percentages

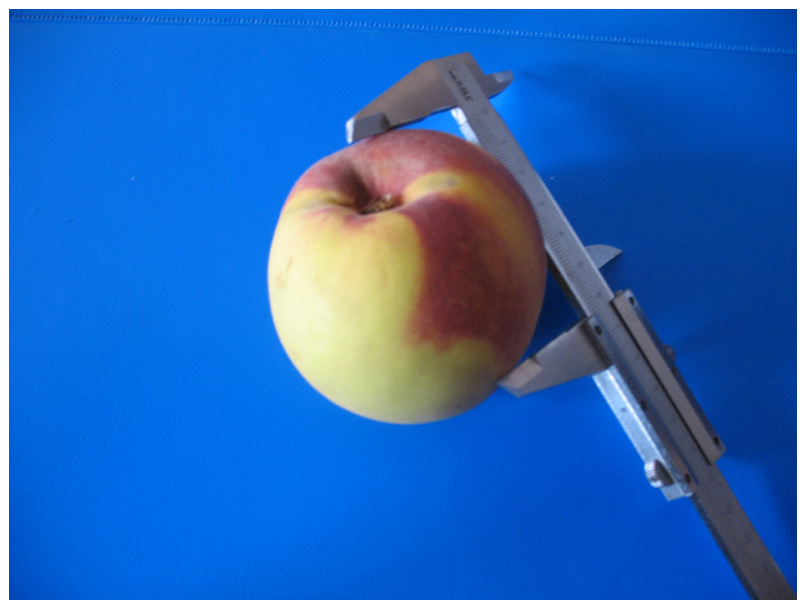

Fig. 6 Determining the biometric characteristics

Tab. 3. The main biometric characteristics of fruits - Peaches from Chile (10 days of storage)

\begin{tabular}{cccccc}
\hline $\begin{array}{c}\text { Number of } \\
\text { days }\end{array}$ & $\begin{array}{c}\text { Diameter } \\
(\mathrm{cm})\end{array}$ & $\begin{array}{c}\text { Circumference } \\
(\mathrm{cm})\end{array}$ & Length $(\mathrm{cm})$ & Weight $(\mathrm{g})$ & Fruit color \\
\hline 6 & $6.75 \pm 0.08$ & $22.58 \pm 0.14$ & $6.56 \pm 0.09$ & $181.45 \pm 1.05$ & Yellow reddish \\
\hline 7 & $6.74 \pm 0.02$ & $22.57 \pm 0.43$ & $6.56 \pm 0.05$ & $181.44 \pm 1.62$ & Yellow reddish \\
\hline 8 & $6.72 \pm 0.04$ & $22.55 \pm 0.52$ & $6.56 \pm 0.04$ & $181.44 \pm 1.25$ & Yellow reddish \\
\hline 9 & $6.72 \pm 0.10$ & $22.55 \pm 0.11$ & $6.55 \pm 0.21$ & $181.43 \pm 0.97$ & Yellow reddish \\
\hline 10 & $6.71 \pm 0.54$ & $22.54 \pm 0.20$ & $6.55 \pm 0.07$ & $181.43 \pm 0.89$ & Yellow reddish \\
\hline
\end{tabular}

Tab. 4. The main biometric characteristics of fruits - Peaches from Turkey (10 days of storage)

\begin{tabular}{cccccc}
\hline $\begin{array}{c}\text { Number of } \\
\text { days }\end{array}$ & $\begin{array}{c}\text { Diameter } \\
(\mathrm{cm})\end{array}$ & $\begin{array}{c}\text { Circumference } \\
(\mathrm{cm})\end{array}$ & Length $(\mathrm{cm})$ & Weight $(\mathrm{g})$ & Fruit color \\
\hline 6 & $6.85 \pm 0.09$ & $22.61 \pm 0.49$ & $6.51 \pm 0.04$ & $181.91 \pm 0.87$ & Yellow reddish \\
\hline 7 & $6.84 \pm 0.05$ & $22.61 \pm 0.70$ & $6.52 \pm 0.12$ & $181.91 \pm 0.61$ & Yellow reddish \\
\hline 8 & $6.82 \pm 0.13$ & $22.60 \pm 0.38$ & $6.54 \pm 0.17$ & $181.74 \pm 1.25$ & Yellow reddish \\
\hline 9 & $6.8 \pm 0.20$ & $22.59 \pm 0.24$ & $6.55 \pm 0.06$ & $181.73 \pm 1.64$ & Yellow reddish \\
\hline 10 & $6.81 \pm 0.04$ & $22.55 \pm 0.50$ & $6.53 \pm 0.51$ & $181.73 \pm 1.30$ & Yellow reddish \\
\hline
\end{tabular}


being recorded in the Turcia $\left(11.32 \%\right.$ to $4{ }^{\circ} \mathrm{C}$ after 10 days of storage) (Fig. 2).

Peach pulp cell walls are related to one another of pectin, which is activated by calcium, which forms a very important component of cell walls of the fruit pulp. Calcium level in the fruit contribute to the integrity and sustainability of fruit tissue, including its firmness. In addition to the varietal characteristics / genetic level of calcium in the fruit is also one of the most important factors determining fruit firmness.

Tab. 5. Fruit classification depending on the biometric size ( http://www.acsa.md/public/publications/540256_md_stonefruit_phh_.pdf )

\begin{tabular}{ccc}
\hline Diameter & $\begin{array}{c}\text { Dimension } \\
\text { code }\end{array}$ & Circumference \\
\hline $90 \mathrm{~mm}$ and more & AAAA & $28 \mathrm{~cm}$ and more \\
\hline $80 \mathrm{~mm}$ and more, but less than $90 \mathrm{~mm}$ & AAA & $25 \mathrm{~cm}$ and more, but less than $28 \mathrm{~cm}$ \\
\hline $73 \mathrm{~mm}$ and more, but less than $80 \mathrm{~mm}$ & AA & $23 \mathrm{~cm}$ and more, but less than $25 \mathrm{~cm}$ \\
\hline $67 \mathrm{~mm}$ and more, but less than $73 \mathrm{~mm}$ & A & $21 \mathrm{~cm}$ and more, but less than $23 \mathrm{~cm}$ \\
\hline $61 \mathrm{~mm}$ and more, but less than $67 \mathrm{~mm}$ & B & $19 \mathrm{~cm}$ and more, but less than $21 \mathrm{~cm}$ \\
\hline $56 \mathrm{~mm}$ and more, but less than $61 \mathrm{~mm}$ & C & $17.5 \mathrm{~cm}$ and moret, but less than $19 \mathrm{~cm}$ \\
\hline $51 \mathrm{~mm}$ and more, but less than $56 \mathrm{~mm}$ & D & $16 \mathrm{~cm}$ and more, but less than $17.5 \mathrm{~cm}$ \\
\hline
\end{tabular}

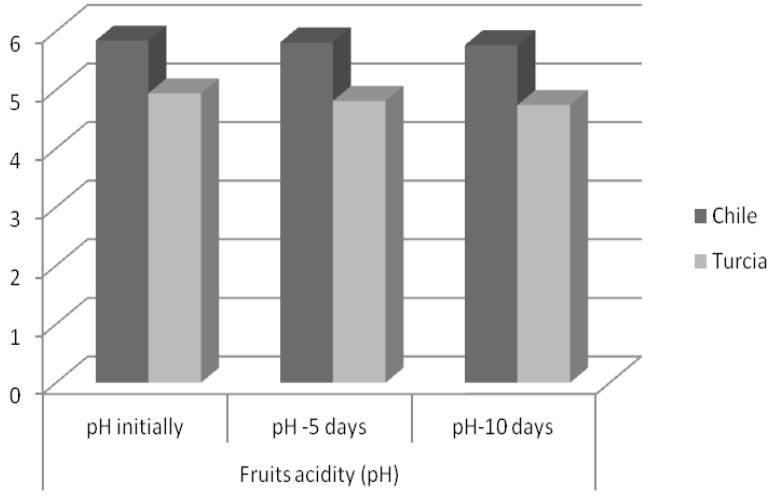

Fig. 7. Results regarding the fruits acidity in tested fruits

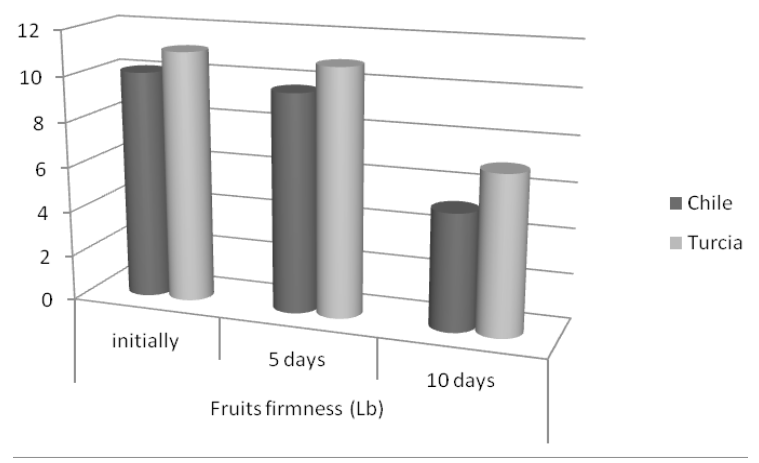

Fig. 9. Results regarding the fruits firmness in tested fruits

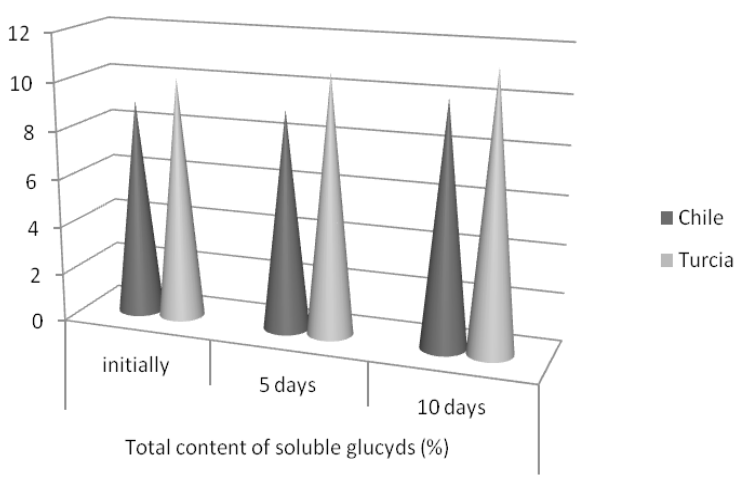

Fig. 8. Results regarding the total content of soluble glucyds in tested fruits

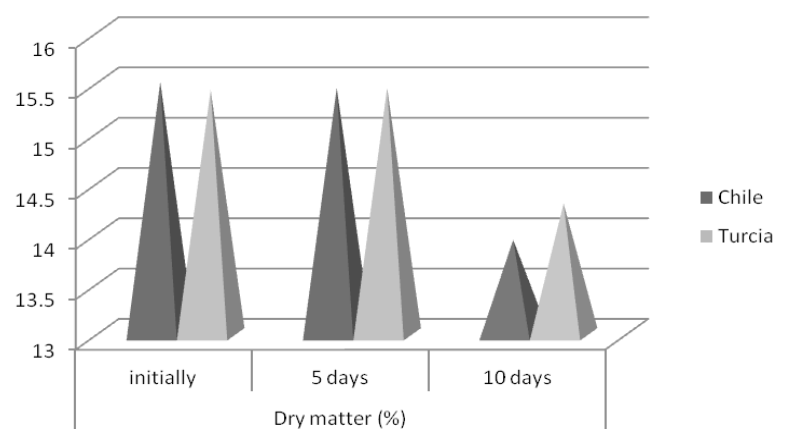

Fig. 10. Results regarding the dry matter percent in tested fruits 
Tab. 6. The framing of fruits depending on the stage of maturity (http://www.acsa.md/public/publications/540256_md_stonefruit_phh_.pdf)

\begin{tabular}{ccccc}
\hline Fruit & Maturity stage $^{*}$ & Firmness (Lb) & CSS (\%) & AT (\% malic acid) \\
\hline Peach & 1 & $13-15$ & $8-9$ & $0.7-0.9$ \\
\hline & 2 & $10-13$ & $9-11$ & $0.5-0.7$ \\
\hline *1= partially mature; 2 = mature; 3 = partially baked. & $7-10$ & $11-14$ & -0.5 \\
\hline
\end{tabular}

During fruit preservation has been a natural tendency to reduce fruit pulp firmness, the sharpest ascertaining the variety Chile with 5.15 $\mathrm{Lb}$, after 10 days of storage at $4^{\circ} \mathrm{C}$, while Turcia showed a less drastic reduction firmness $(6.98 \mathrm{Lb})$ resulting in the preservation for a period of time (Fig. 3).

Experiments have shown that the tested peach fruit is a decrease during preservation in terms of dry matter content. In terms of percentage of dry matter at $4{ }^{\circ} \mathrm{C}$, the lowest value was found Chile variety by $13.94 \%$ and the highest value was recorded for the Turcia with $14.30 \%$, after 10 days of storage (Fig. 4).

As regarding the biochemical characteristics, after 5 days of conservation can be seen a reduction in fruit firmness, however there is an increase of soluble carbohydrate content, while vegetable juice acidity and dry matter percentage recorded no significant changes.

The values recorded for biochemical characteristics of the two types of peaches provide information regarding on their degree of maturity, they fitted into the category of "mature" (Tab. 6).

\section{CONCLUSION}

After the analysis of the main biometric (diameter, length, weight) it is found that after 10 days of storage, due to post-maturation processes, in particular respiratory (degradation of organic substrate) is a reduction of diameter, circumference, length and weight at all peach varieties tested.

In the case of physical parameters the two types of peaches studied values are significantly close due to their classification in the same class quality, A.

The values recorded for biochemical characteristics of the two types of peaches provide important information on their degree of maturity, they fitting into the category of "mature".

As regarding the biochemical characteristics, after 5 days of conservation can be seen a reduction in fruit firmness, however there is an increase of soluble carbohydrate content, while vegetable juice acidity and dry matter percentage recorded no significant changes.

In case of biochemical parameters after 10 days of conservation there is a continuous trend to increase the soluble carbohydrate content due to conversion of starch into glucose after enzymatic hydrolysis processes and also there is a sharp decrease in fruit firmness, but also a slight decrease of the juice acidity from the pulp of the fruit.

\section{REFERENCES}

1. Abeles FB, Morgan PW, Saltveit Jr. ME (1992). Ethylene in Plant Biology. 2E Ed. Academic Press, Inc. San Diego, California U.S.A. 414

2. Aly MM, El Agamy SZA, Biggs RH (1981). Ethylene production and firmness of peach and nectarine fruits as related to storage. Proc Fla. State Hort. Soc. 94:291-294.

3. Blankenship SM, Dole JM (2003). 1-Methylcyclopropene: a review. Postharvest Biol. Technol. 28:1-25.

4. Blanpied DG (1975). Core breakdown of New York 'Bartlett' pears, J. Am. Soc. Hort. Sci., 100:198-200.

5. Budde CO, Blanco MP, Altube HA (2000). Fruit firmness, ground color and ethylene evolution in two cultivars of peach (Prunus persica L. Batsch), Agriscientia, XVII: 6972.

6. Franck C, Lammertyn J, Quang TH, Verboven P, Verlinden B, Bart MN (2007). Browning disorders in pear fruit, Postharvest Biology and Technology, Volume 43(1):1-13.

7. Lammertyn J, Scheerlinck N, Jancsók P, Verlinden BE, Nicolaï BM (2003). A respiration-diffusion model for Conference pears I: model development and validation. Postharvest Biol. Technol., 30:29-42.

8. Pech JC, Balague C, Latche A, Bouzayen M (1994). Post-harvest physiology of climacteric fruits: recent 
developments in the biosynthesis and action of ethylene. Scences des Aliments, 14:3-15.

9. Tonutti P, Casson P, Ramina A (1991). Ethylene Biosynthesis during Peach Fruit Development. J. Amer. Soc. Hort. Sci. 116(2):274-279.
10. Tonutti P, Bonghi C, Ramina A (1996). Fruit Firmness and ethylene biosynthesis in three cultivars of peach (Prunus persica L. Batsch) J. Hort. Sci. 71(1):141-147.

11. http://www.acsa.md/public/publications/532252 md_458206_md_proto.pdf

12. http://www.acsa.md/public/publications/540256_md_ stonefruit_phh_.pdf 